\title{
Precompression stress and compression index depend on the property used to represent the soil deformation in the compression curve
}

\author{
Pressão de preconsolidação e índice de compressão dependem da propriedade \\ usada para representar a deformação do solo na curva de compressão
}

\author{
Paulo Ivonir Gubiani ${ }^{I^{*}}$ Quirijn de Jong Van Lier ${ }^{\mathrm{II}}$ José Miguel Reichert \\ Rafael Ziani Goulart ${ }^{I I I}$ Eracilda Fontanela ${ }^{\text {IV }}$
}

\section{ABSTRACT}

During linear deformation (h) in a soil sample, the variation of the void ratio with respect to deformation (de/dh) and the respective variation of soil bulk density $(\mathrm{d} \rho / \mathrm{dh})$ are identical only for a specific value of $h$. Consequently, if two compression curves are drawn for the same soil sample, one using $\rho$ and the other using $\varepsilon$, there are differences in both the calculated precompression stress ( $\sigma p)$ and compression index (Ic). In this study, we highlight the causes by a mathematical analysis and an experimental investigation, quantifying the differences in $\sigma p$ and Ic when using $\varepsilon$ and $\rho$. $\sigma p$ and Ic were calculated for 103 compression curves of an ultisol and 193 of an oxisol. The $\sigma p(\mathrm{kPa})$ using $\rho$ $(\sigma p)$ was greater than when using $\varepsilon\left(\sigma p_{2}\right)$, and differences were rather independent of the soil type. The relations found by linear regression relating $\sigma p_{\rho}$ to $\sigma p_{\varepsilon}$ were $\sigma p_{\rho}=0.8186 \sigma p_{\varepsilon}+34.202$ for the ultisol and $\sigma p=0.8878 \sigma p+34.875$ for the oxisol. In contrast, the used soil property ( $\rho$ or $\varepsilon$ ) as well as soil type affected Ic. Ic calculated using $\rho$ was greater than when using $\varepsilon$ in almost all (96\%) of the cases for the ultisol, and in only $12 \%$ of the cases for the oxisol. For a wide range of $\rho$, evidence from this study indicated that the use of $\rho$ overestimates $\sigma p$ when compared to the use of $\varepsilon$.

Key words: void ratio, particle density, soil bulk density.

\section{RESUMO}

À medida que uma amostra de solo sofre deformação linear (h), a variação do indice de vazios em relação à deformação

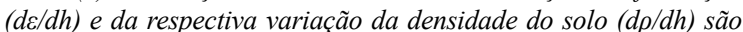
coincidentes somente para um único valor de h. Decorrente disso, verifica-se experimentalmente que, para a mesma amostra de solo, há diferenças, tanto na pressão de preconsolidação $(\sigma p)$ como no indice de compressão (Ic), se forem determinados a partir das duas curvas de compressão, uma a base da $\rho$ e outra a base do $\varepsilon$.
A análise matemática, seguida da investigação experimental deste estudo, evidencia as causas e quantifica as diferenças na $\sigma p$ e no Ic, devido ao uso do $\varepsilon$ ou $\rho$. A op e o Ic foram calculados em 103 curvas de compressão de um Argissolo e em 193 de um Latossolo. A $\sigma p\left(\mathrm{kPa}\right.$ ) com o uso da $\rho$ ( $\left.\sigma p_{\beta}\right)$ foi maior que a $\sigma p$ com o uso do $\varepsilon$ ( $\sigma p)$, e as diferenças dependeram menos do tipo de solo. As relações encontradas por regressão foram $\sigma p_{\rho}=0,8186 \sigma p_{\varepsilon}+34,202$ para o Argissolo e $\sigma p=0,8878 \sigma p+34,875$ para $o$ Latossolo. Diferentemente, o Ic foi afetado pela propriedade usada ( $\rho$ ou $\varepsilon$ ) para descrever a deformação e pelo tipo de solo. O Ic calculado com o uso da $\rho$ foi maior que quando calculado com o uso do e em quase todos os casos (96\%) no Argissolo e raramente (em 12\% dos casos) no Latossolo. Para uma ampla faixa de $\rho$, as evidências deste estudo indicam que o uso da $\rho$ superestima a $\sigma p$ em relação ao uso do $\varepsilon$.

Palavras-chave: indice de vazios, densidade dos sólidos, densidade do solo.

\section{INTRODUCTION}

The compression curve $(C C)$ is widely used for obtaining the load-bearing capacity and susceptibility to compaction of soils, expressed by the precompression stress $(\sigma p)$ and the compression index (Ic), respectively (KELLER et al., 2011). To quantify changes in soil structure with the $C C$, some researchers use bulk density $(\rho), C C$, (DIAS JUNIOR \& PIERCE, 1995; FRITTON., 2001; ASSOULINE et al., 2002) whereas others use the void ratio $(\varepsilon), C C \varepsilon$, (GREGORY et al., 2006; CAVALIERI et al., 2008; KELLER et

\footnotetext{
IDepartamento de Solos, Centro de Ciências Rurais (CCR), Universidade Federal de Santa Maria (UFSM), 97105-900, Santa Maria, RS, Brasil. E-mail: paulogubiani@gmail.com. "Corresponding author.

"Laboratório de Física do Solo, Centro de Energia Nuclear na Agricultura (CENA), Universidade de São Paulo, Piracicaba, SP, Brasil.

IIInstituto Federal Farroupilha, Campus Alegrete, Alegrete, RS, Brasil.

${ }^{\text {IV } U n i v e r s i d a d e ~ F e d e r a l ~ d o ~ P a m p a ~(U N I P A M P A), ~ A l e g r e t e, ~ R S, ~ B r a s i l . ~}$
} 
al., 2011; ROSA et al., 2011). Experimentally it is observed that there are differences between the $\sigma p$ and $I c$ values in the same soil sample estimated with both curves, $C C_{\rho}$ and $C C_{\varepsilon}$ (MOSADDEGHI et al., 2003; RÜCKNAGEL et al., 2010). There is evidence that the $\sigma p$ obtained with $\rho\left(\sigma p_{\rho}\right)$ is greater than the $\sigma p$ obtained with $\varepsilon\left(\sigma p_{\varepsilon}\right)$. MOSADDEGHI et al. (2003) presented the relation $\sigma p_{\rho}=1.3 \sigma p_{\varepsilon}$ and RÜCKNAGEL et al. (2010) presented $\sigma p_{\rho}=1.08+7.73 \sigma p_{\varepsilon}(\mathrm{kPa})$, both resulting in $\sigma p_{\rho}$ values higher than $\sigma p_{\varepsilon}$.

The fact there are differences between $\sigma p_{\rho}$ and $\sigma p_{\varepsilon}$ indicates that differences between the values of $I c$ ( $I c_{\rho}$ and $I c_{\varepsilon}$ ) are also to be expected. Both for theoretical reasons, as well as for applications it is useful to know the causes and soil properties that determine the magnitude and direction of the differences. According to MOSADDEGHI et al. (2003) and RÜCKNAGEL et al. (2010), the cause of the differences is the non-linearity of the relationship between $\varepsilon$ and $\rho$. However, these authors did not investigate mathematically the effect of this nonlinearity on $\sigma p$ and $I c$.

As $\varepsilon$ and $\rho$ are reciprocal and the relation between them depends on the (solid) particle density, the aim of this study was to analyze the effect of initial bulk density and particle density on the relation between $\sigma p$ and $I c$ with $\varepsilon$ and $\rho$, theoretically, and experimentally in compression curves of an ultisol and an oxisol.

\section{MATERIALS AND METHODS}

Theory

Initially, two quantities were defined, bulk density $\left(\rho, \mathrm{kg} \mathrm{m}^{-3}\right)$ and void ratio $\left(\varepsilon, \mathrm{m}^{3} \mathrm{~m}^{-3}\right)$, as:

$$
\begin{gathered}
\rho=\frac{M_{s}}{V_{t}} \\
\varepsilon=\frac{V_{v}}{V_{s}}
\end{gathered}
$$

$M_{s}(\mathrm{~kg})$ being the mass of solids, $V_{t}\left(\mathrm{~m}^{3}\right)$ the total soil volume, $V_{v}\left(\mathrm{~m}^{3}\right)$ the void volume (pores) and $V_{s}\left(\mathrm{~m}^{3}\right)$ the volume of soil solids.

As will be shown in the following, the relationship between $\varepsilon$ and $\rho$ is defined solely by the particle density $\rho_{s}\left(\mathrm{~kg} \mathrm{~m}^{-3}\right)$ given by

$$
\rho_{s}=\frac{M_{s}}{V_{s}}
$$

Multiplying equations (1) and (2) and combining with (3) yields

$$
\begin{gathered}
\rho \varepsilon=\frac{M_{s}}{V_{t}} \frac{V_{v}}{V_{s}}=\rho_{s} \frac{V_{v}}{V_{t}} \Leftrightarrow \varepsilon=\frac{\rho_{s}}{\rho} \frac{V_{v}}{V_{t}} \\
\text { As } V_{v}=V_{t}-V_{s} \text { it follows that } \\
\frac{V_{v}}{V_{t}}=\frac{V_{t}-V_{s}}{V_{t}}=1-\frac{V_{s}}{V_{t}}=1-\frac{V_{t}}{M_{s} / V_{s}}=1-\frac{\rho}{\rho_{s}}
\end{gathered}
$$

Substituting equation (5) in (4) we find:

$\varepsilon=\frac{\rho_{s}}{\rho}\left(1-\frac{\rho}{\rho_{s}}\right)=\frac{\rho_{s}}{\rho}-1$

Equation (6) shows that $\rho$ and $\varepsilon$ are inversely proportional, the particle density being the proportionality coefficient.

Based on these definitions and relations, the effect of the use of $\varepsilon$ and $\rho$ in determining $\sigma p$ and $I c$ can be analyzed with the deformation of a soil sample as a function of the initial bulk density and the particle density. Being $H(\mathrm{~m})$ the height of a cylinder containing a soil sample and $h_{1}(\mathrm{~m})$ the linear deformation when submitted to load (pressure), the resulting sample height $h_{2}(\mathrm{~m})$ is given by:

$$
\mathrm{h}_{2}=\mathrm{H}-\mathrm{h}_{1}
$$

Although $h$ is the height of the sample after a deformation $h_{1}$, in our case it is more convenient to use $H-h_{1}$, as it is our objective to analyze the relation of both $\varepsilon$ and $\rho$ with $h_{1}$.

At any time during the compression, the soil volume $V_{t}$ is given by:

$$
V_{t}=\pi r^{2}\left(H-h_{1}\right)
$$

and the volume of soil solids, $V$, which is not affected by compaction, is expressed by rewriting equation (3):

$$
V_{s}=\frac{M_{s}}{\rho_{s}}
$$

The void volume $V_{v}$ is given by:

$V_{v}=V_{t}-V_{s}=\pi r^{2}\left(H-h_{l}\right)-\frac{M_{s}}{\rho_{s}}$

from which the void ratio $\varepsilon$ is obtained as: $\varepsilon=\frac{V_{v}}{V_{s}}=\frac{\pi r^{2}\left(H-h_{l}\right)-\frac{M_{s}}{\rho_{s}}}{\frac{M_{s}}{\rho_{s}}}=\frac{\pi r^{2} \rho_{s}\left(H-h_{l}\right)}{M_{s}}-1$

Finally, the bulk density $\rho$ is given by:

$\rho=\frac{M_{s}}{V_{t}}=\frac{M_{s}}{\pi r^{2}\left(H-h_{l}\right)}$

Variations of $\varepsilon$ and $\rho$ as a function of $h_{1}$ can be calculated from equations (11) and (12) that reflect the relation described in equation (6): 


$$
\begin{aligned}
& \frac{d \varepsilon}{d h_{l}}=-\frac{\pi r^{2} \rho_{s}}{M_{s}}\left(\mathrm{~m}^{-1}\right) \\
& \frac{d \rho}{d h_{1}}=-\frac{M_{s}}{\pi r^{2}\left(H-h_{1}\right)^{2}}\left(\mathrm{~kg} \mathrm{~m}^{-4}\right)
\end{aligned}
$$

Equations (13) and (14) show that $\mathrm{d} \varepsilon / \mathrm{d} h$ is a constant, unlike $\mathrm{d} \rho / \mathrm{d} h_{1}$, which is a function of $h_{1}$. A direct comparison between the two derivatives represented in equations (13) and (14) does not make sense because they have different dimensions (units). To allow comparison, equation (12) is divided by the density of water, resulting in a relative density $\left(\rho_{r}\right)$ :

$$
\rho_{r}=\frac{\rho}{\rho_{a}}=\frac{M_{s}}{\rho_{a} \pi r^{2}\left(H-h_{1}\right)}
$$

is given by:

The variation rate of $\rho_{r}$ as a function of $h_{1}$

$\frac{d \rho_{r}}{d h_{1}}=-\frac{M_{s}}{\rho_{a} \pi r^{2}\left(H-h_{1}\right)^{2}}\left(\mathrm{~m}^{-1}\right)$

Equations (13) and (16) have the same dimension and can be compared to find the values of $h_{1}$ and $\rho$ that correspond to the same rate of variation, respectively, $h_{l, x}(\mathrm{~m})$ and $\rho_{x}\left(\mathrm{~kg} \mathrm{~m}^{-3}\right)$ :

$$
\begin{aligned}
& \frac{M_{s}}{\rho_{a} \pi r^{2}\left(H-h_{1, x}\right)^{2}}=\frac{\pi r^{2} \rho_{s}}{M_{s}} \\
& \frac{M_{s} M_{s}}{\pi r^{2}\left(H-h_{1, x}\right) \pi r^{2}\left(H-h_{1, x}\right)}=\rho_{s} \rho_{a} \\
& \rho_{x}{ }^{2}=\rho_{s} \rho_{a} \Rightarrow \rho_{x}=\sqrt{\rho_{s} \rho_{a}}
\end{aligned}
$$

In other words, $\rho_{x}$, the bulk density for which $d \varepsilon / d h_{1}$ and $d \rho_{r} / d h_{1}$ will be equal, is the geometric mean of particle and water density.

As $\mathrm{d} \rho_{r} / \mathrm{d} h_{1}$ decreases with $h_{1}$ and $\mathrm{d} \varepsilon / \mathrm{d} h_{1}$ is a negative constant, $\mathrm{d} \rho / \mathrm{d} h h_{1}$ will be less negative than $\mathrm{d} \varepsilon /$ $\mathrm{d} h_{1}$ when $\rho<\rho_{x}$. For $\rho>r_{x}$, the relation becomes inverse (Figure 1). This indicates that $C C_{\varepsilon}$ is different from $C C_{\rho}$ for all values of $\rho$ except $\rho_{x}$. However, it does not allow concluding that the use of $\rho$ will always overestimate $\sigma_{p}$ when compared to the use of $\varepsilon$ for the range of agricultural bulk densities, as observed by MOSADDEGHI et al. (2003) and RÜCKNAGEL et al. (2010).

The matter can be investigated experimentally, considering soils with different $\rho_{s}$ and samples with different initial bulk density. The mathematical procedure should be the same for the description of both curves, $C C_{\varepsilon}$ and $C C_{\rho}$ in order to avoid differences caused by the mathematical models themselves (GREGORY et al., 2006; CAVALIERI et al., 2008; ROSA et al., 2011).

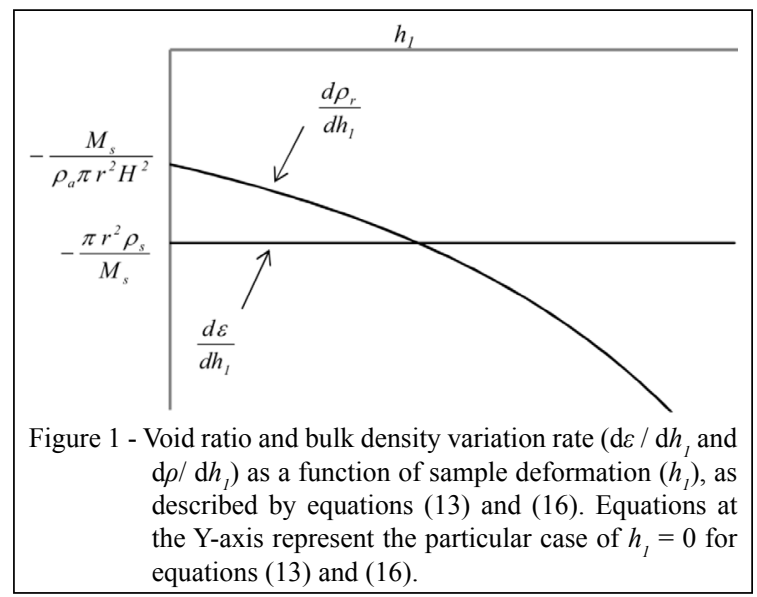

Experiment

A study was performed with 103 samples of an ultisol and 193 samples of an oxisol, according to Soil Taxonomy developed by USDA (SOIL SURVEY STAFF, 2010). Samples were collected in experimental plots with different levels of soil compaction (no-till, no-till with additional traffic to enhance compaction and no-till with scarification to decrease compaction). Sampling was performed in these experiments at some depths to obtain a wide range in bulk density required for this study.

In the ultisol $\left(0.10 \mathrm{~kg} \mathrm{~kg}^{-1}\right.$ clay, $0.65 \mathrm{~kg}$ $\mathrm{kg}^{-1}$ sand and $0.25 \mathrm{~kg} \mathrm{~kg}^{-1}$ silt), undisturbed samples were collected at depths of $0.05,0.15$ and $0.30 \mathrm{~m}$ in stainless steel rings $(0.057 \mathrm{~m}$ in diameter and $0.03 \mathrm{~m}$ in height). In the oxisol $\left(0.12 \mathrm{~kg} \mathrm{~kg}^{-1}\right.$ sand, $0.24 \mathrm{~kg} \mathrm{~kg}^{-1}$ silt and $0.64 \mathrm{~kg} \mathrm{~kg}{ }^{1}$ clay), undisturbed samples were collected at depths of 0.07 and $0.25 \mathrm{~m}$ in stainless steel rings $(0.061 \mathrm{~m}$ diameter and $0.03 \mathrm{~m}$ height). Prior to the compression test, the samples were saturated with water by capillarity and submitted to the tension of $10 \mathrm{kPa}$ (both ultisol and oxisol) on a sand box (REINERT \& REICHERT, 2006), and to 33, 100, 500 and $1500 \mathrm{kPa}$ (only the oxisol) in pressure chamber (KLUTE, 1986). At each pressure, the samples were weighed to determine the volumetric water content $\left(\theta, \mathrm{m}^{3} \mathrm{~m}^{-3}\right)$ and the degree of saturation $(\mathrm{S}=\theta / \alpha$, where $\alpha$ is the total porosity, $\mathrm{m}^{3} \mathrm{~m}^{-3}$ ) and were subjected to compression test.

The particle density $\rho_{s}$ was determined in 25 samples of the ultisol and 48 samples of the oxisol by the volumetric flask method with modifications proposed by GUBIANI et al. (2006). For the ultisol, $\rho_{s}$ was $2650 \mathrm{~kg} \mathrm{~m}^{-3}$ (standard deviation $52 \mathrm{~kg} \mathrm{~m}^{-3}$ ) and for the oxisol $2720 \mathrm{~kg} \mathrm{~m}^{-3}$ (standard deviation $65 \mathrm{~kg} \mathrm{~m}^{-3}$ ).

Uniaxial compression tests were performed in a consolidometer, model Terraload S-450 (Durham 
Geo-Enterprises). Successive loadings of 12.5, 25, 50, $100,200,400,800$ and $1600 \mathrm{kPa}$ were applied. Each loading was applied during five minutes, enough to achieve $99 \%$ of total deformation (SILVA et al., 2000). At the end of the test, the samples were oven-dried at $105^{\circ} \mathrm{C}$ until constant weight. Structure changes of the sample for each loading were represented by $\varepsilon$ (equation 11) and $\rho$ (equation 12).

Both $\sigma p$ and $I c$ were calculated with the procedure proposed by DIAS JUNIOR \& PIERCE (1995). Although this procedure was originally described with a compression curve $C C_{\rho}$, it can also be used with a compression curve and $C C_{\varepsilon}$ (CAVALIERI et al., 2008). In summary, $\sigma p$ corresponds to the value of load at the intersection of the secondary compression line (drawn based on three data points for $\left(\log _{10} \sigma, \varepsilon\right)$ or $\left(\log _{10} \sigma, \rho\right)$ at loadings of $12.5,25$ and $50 \mathrm{kPa}$ ) with the virgin compression line (drawn based on the final four data points $\left(\log _{10} \sigma, \varepsilon\right)$ or $\left(\log _{10} \sigma, \rho\right)$ at loadings of $200,400,800$ and $1600 \mathrm{kPa}]$. Unlike the original method of DIAS JUNIOR \& PIERCE (1995), which uses two data points $\left(\log _{10} \sigma, \rho\right)$ at loadings of 800 and $1600 \mathrm{kPa}$ to draw the virgin compression line, in the present study it was decided to use the four data points due to the fact that the two final points alone would not represent well the observed tendency which is slightly sigmoid in its tail. In these cases, the use of only the two final data points like proposed by DIAS JUNIOR \& PIERCE (1995) would make the projection of the virgin compression line to intercept the line of secondary compression in the domain $\sigma<\sigma_{50 k P a}$, in disagreement with the definition of the virgin compression line as the line segment subsequent to the secondary compression line (DIAS JUNIOR \& PIERCE, 1995; GREGORY et al., 2006; KELLER et al., 2011). The use of the four final data points avoid that two data point (at loadings of 800 and $1600 \mathrm{kPa}$ ) would be excluded, and to ensure that the line of virgin compression would intercept the line of secondary compression within the domain $\sigma>\sigma_{50 k P a}$.

Regardless of the curve shape, the choice of data points changes estimates for $\sigma p$ and $I c$ in the same direction (either an increase or a decrease, irrespective of using $\rho$ or $\varepsilon$ ). Furthermore, the magnitude of change in $\sigma p_{\rho}$ and $I c$ is different of that in $\sigma p_{\varepsilon}$ and $I c_{\varepsilon}$. However, the choice of the final data points only increases or decreases these magnitudes, because the cause of differences is the intrinsic nonlinearity of the relationship between $\rho$ and $\varepsilon$ shown above. Although the experimental results are affected by the procedure used, they only particularize but do not invalidate neither the discussion nor the conclusions of this study. Finally, Ic was defined as the absolute value of the slope of the virgin compression line. More details of the procedure are described in DIAS JUNIOR \& PIERCE (1995).

The $\sigma p$ calculated using $\varepsilon$ was correlated to $\sigma p$ calculated using $\rho$ by linear regression. The comparison of the calculated $I c$ using $\varepsilon$ and $\rho$ was made by comparison of the respective slopes of the virgin compression line.

\section{RESULTS AND DISCUSSION}

There was a large variation in values of $\rho, \varepsilon$ and $S$ for the used samples (Table 1), indicating structural differences of the soil and different water contents leading to a wide range of $\sigma p$ values. The values of $\sigma p$ (average \pm standard deviation) were $112( \pm 30) \mathrm{kPa}$ for the ultisol and $133( \pm 46) \mathrm{kPa}$ for the oxisol.

For both soils, values of $\sigma p$ calculated based on $\rho\left(\sigma p_{\rho}\right)$ were higher than when calculated using $\varepsilon\left(\sigma p_{\varepsilon}\right)$ (Figure 2A, B). Differences between $\sigma p_{\rho}$ and $\sigma p_{\varepsilon}$ were $34 \mathrm{kPa}$ at maximum, and were higher in samples with a low $\sigma p$. Linear and angular regression coefficients for $\sigma p_{\rho}$ as a function of $\sigma p_{\varepsilon}$ were similar for both soils (linear 34.2 versus $34.9 \mathrm{kPa}$ and angular 0.82 versus $0.89 \mathrm{kPa} \mathrm{kPa}^{-1}$ for the ultisol and oxisol, respectively), indicating that the relation between $\sigma p_{\rho}$ and $\sigma p_{\varepsilon}$ is not (much) affected by soil type. Based on the $95 \%$ confidence interval, regressions were similar for $\sigma p_{\varepsilon}<40 \mathrm{kPa}$ and different for higher values, but with a small difference. Numerically, these regression coefficients are different from the coefficients

Table 1 - Descriptive statistics for the soil samples.

\begin{tabular}{|c|c|c|c|c|}
\hline Property * & Mean & $\begin{array}{l}\text { Standard } \\
\text { deviation }\end{array}$ & Minimum & Maximum \\
\hline & \multicolumn{4}{|c|}{ 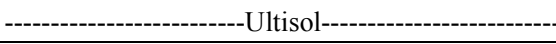 } \\
\hline$\rho_{i}$ & 1619 & 154 & 1206 & 1964 \\
\hline$\rho_{f}$ & 1917 & 94 & 1661 & 2178 \\
\hline$\varepsilon_{i}$ & 0.65 & 0.17 & 0.35 & 1.20 \\
\hline$\varepsilon_{f}$ & 0.39 & 0.07 & 0.22 & 0.60 \\
\hline \multirow[t]{2}{*}{$S_{i}$} & 0.55 & 0.12 & 0.15 & 0.80 \\
\hline & & $------O x$ & sol--------- & ------------. \\
\hline$\rho_{i}$ & 1318 & 114 & 982 & 1557 \\
\hline$\rho_{f}$ & 1720 & 81 & 1403 & 1941 \\
\hline$\varepsilon_{i}$ & 1.08 & 0.19 & 0.75 & 1.77 \\
\hline$\varepsilon_{f}$ & 0.59 & 0.08 & 0.40 & 0.94 \\
\hline$S_{i}$ & 0.66 & 0.13 & 0.28 & 0.89 \\
\hline
\end{tabular}

* initial $\left(\rho_{i}\right)$ and final $\left(\rho_{f}\right)$ bulk density $\left(\mathrm{kg} \mathrm{m}^{3}\right)$, initial $\left(\varepsilon_{i}\right)$ and final $\left(\varepsilon_{f}\right)$ void ratio $\left(\mathrm{m}^{3} \mathrm{~m}^{-3}\right)$, initial degree of saturation $\left(S_{i}\right)$.

Ciência Rural, v.46, n.1, jan, 2016. 

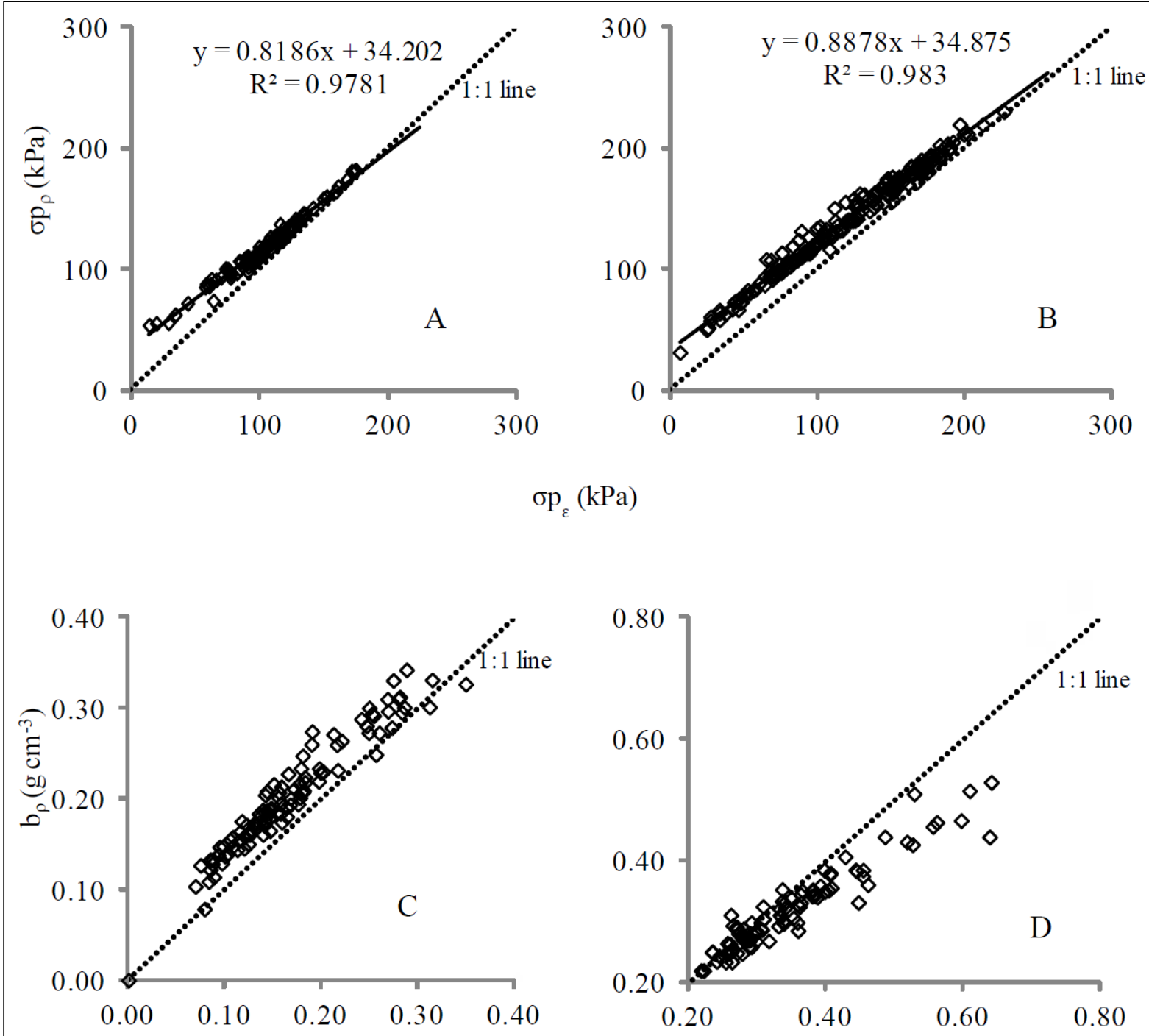

$\mathrm{b}_{\varepsilon}$

Figure 2 - Precompression stress calculated using bulk density $\left(\sigma p_{\rho}\right)$ versus using void ratio $(\sigma p)$ for the ultisol (A) and the oxisol (B); and the relation between the absolute value of slope of the virgin compression line using bulk density $\left(b_{\rho}\right)$ and using void ratio $\left(b_{\varepsilon}\right)$ for the ultisol (C) and the oxisol (D).

presented by MOSADDEGHI et al. (2003), $\sigma p_{\rho}=1.3 \sigma p_{\varepsilon}$ and by RÜCKNAGEL et al. (2010), $\sigma p_{\rho}=1.08 \sigma p_{\varepsilon}+7.73$, possibly due to the methodological differences in the calculation of $\sigma p$. However, all experimental relations show $\sigma p_{\rho}$ to be greater than $\sigma p_{\varepsilon}$.

The differences between $\sigma p_{\rho}$ and $\sigma p_{\varepsilon}$ $\left(\Delta \sigma p=\sigma p_{\rho}-\sigma p_{\varepsilon}\right)$ decreased linearly with the initial bulk density $\left(\rho_{i}\right)$ for both soils. For the ultisol, $\Delta \sigma p=-0.039 \rho_{i}+77.89\left[\mathrm{R}^{2}=0.7026\right]$ and for the oxisol $\Delta \sigma_{p}=-0,051 \rho_{i}+88.564\left[\mathrm{R}^{2}=0.592\right]$. Based on these equations, $\Delta \sigma p$ would be negative for values of $\rho_{i}$ greater than $1997 \mathrm{~kg} \mathrm{~m}^{-3}$ for the ultisol and greater than $1736 \mathrm{~kg} \mathrm{~m}^{-3}$ for the oxisol. These bulk density values are much higher than those found in these soils, indicating that the use of $\rho$ will always overestimate $\sigma p$ when compared to employing $\varepsilon$.

The compression ratio $I c$, which is the absolute value of the slope of the part of the compression curve (bulk density or void ratio as a function of applied load) that corresponds to plastic deformation, the so-called "virgin compression line", was affected both by the property used to describe the soil deformation as by the soil type (Figure 2C, D). The $I c$ calculated using $\rho$ was higher than when using 
$\varepsilon$ in almost all cases $(96 \%)$ in the ultisol and rarely (12\% of cases) in the oxisol. This difference between both soils can be explained by the $\rho$ ratio reached by the samples on the virgin compression line segment with the respective value of $\rho_{x}$ (equation 19). For the ultisol, $\rho_{x}$ equaled $\sqrt{ }(2650 \cdot 1000)=1628 \mathrm{~kg} \mathrm{~m}^{-3}$ and for the oxisol it was $\sqrt{ }(2720 \cdot 1000)=1649 \mathrm{~kg} \mathrm{~m}^{-3}$. Note that the $\rho_{x}$ values depend only on the particle density $\left(2650 \mathrm{~kg} \mathrm{~m}^{-3}\right.$ and $2720 \mathrm{~kg} \mathrm{~m}^{-3}$ for the ultisol and oxisol, respectively), wherein one of the factors determines the difference between $\mathrm{d} \varepsilon / \mathrm{d} h_{1}$ and $\mathrm{d} \rho / \mathrm{d} h_{1}$.

In the ultisol, $93 \%$ of soil $\rho$ were higher than its $\rho_{x}\left(1628 \mathrm{~kg} \mathrm{~m}^{-3}\right)$, indicating that in these cases, the rate of variation of $\rho$ was greater than for $\varepsilon$ (Figure 1). Consequently, in most cases, Ic calculated using $\rho$ was higher than when using $\varepsilon$ (Figure $2 \mathrm{C}, \mathrm{D}$ ). In contrast, in the oxisol, only $31 \%$ of the $\rho$ were higher than its $\rho_{x}\left(1649 \mathrm{~kg} \mathrm{~m}^{-3}\right)$, resulting in a rate of variation of $\varepsilon$ greater than that of $\rho$ in $85 \%$ of the cases (Figure 1). Consequently, in most cases, the $I c$ calculated using $\varepsilon$ was greater than when calculated using $\rho$ (Figure 2C, D).

Based on this analysis, $\sigma p$ and $I c$ depends on the property used to describe the deformation of the soil. Consequently, the comparison of results of $\sigma p$ and $I c$ in several publications (GREGORY et al., 2006; CAVALIERI et al., 2008; KELLER et al., 2011; ROSA et al., 2011) is not suitable, because the differences in $\sigma p$ and $I c$ are partially caused by the soil property used and therefore may not accurately represent differences in the mechanical behavior of soils. Similarly, comparison of mathematical models that describe the compression curve based on $\rho$ (DIAS JUNIOR \& PIERCE, 1995; FRITTON, 2001; ASSOULINE et al., 2002) with those models that employ $\varepsilon$ (GREGORY et al., 2006, CAVALIERI et al., 2008; KELLER et al., 2011) may also contains such errors. These problems can be avoided if all comparisons are made with $\sigma p$ and $I c$ calculated with the same mathematical model and soil property.

\section{CONCLUSIONS}

Precompression stress and the compression index differ between compression curves based on bulk density and void ratio due to the non-linearity of the relationship between these soil properties. The difference depends on the initial bulk density and the particle density. For a wide range of initial bulk densities, results with the two soils used in this study indicate that the use of bulk density overestimates the precompression stress when compared to the use of the void ratio.

\section{ACKNOWLEDGEMENTS}

The authors owe thanks to the Conselho Nacional de Desenvolvimento Científico e Tecnológico (CNPq) for research grants.

\section{REFERENCES}

ASSOULINE, S. Modeling soil compaction under uniaxial compression. Soil Science Society of America Journal, v.66, n.6, p.1784-1787, 2002.

CAVALIERI, K.M.V. et al. Determination of precompression stress from uniaxial compression tests. Soil and Tillage Research, v.98, n.1, p.17-26, 2008. Available from: <http://www.sciencedirect. com/science/article/pii/S0167198707001717>. Accessd: Jan. 08, 2013. doi:10.1016/j.still.2007.09.020.

DIAS JUNIOR, M.S; PIERCE, F.J. A simple procedure for estimating preconsolidation pressure from soil compression curves. Soil Technology, v.8, n.2, p.139-151, 1995. Available from: <http:// www.sciencedirect.com/science/article/pii/0933363095000158>. Accessed: Jan. 08, 2013. doi: 10.1016/0933-3630(95)00015-/8.

FRITTON, D.D. An improved empirical equation for uniaxial soil compression for a wide range of applied stresses. Soil Science Society of America Journal, v.65, n.3, p.678-684, 2001.

GREGORY, A.S. et al. Calculation of the compression index and precompression stress from soil compression test data. Soil and Tillage Research, v.89, n.1, p.45-57, 2006. Available from: $<$ http:// www.sciencedirect.com/science/article/pii/S0167198705001868>. Accessed: Jan. 08, 2013. doi: 10.1016/j.still.2005.06.012.

GUBIANI, P.I. et al. Alternative method to measure the soil particle density - exactness, precision, and processing time. Ciência Rural, v.36, n.2, p.664-668, 2006. Available from: <http://www.scielo.br/ scielo.php?script=sci_arttext\&pid=S0103-84782006000200049>. Accessed: Feb. 05, 2014. doi:10.1590/S0103-84782006000200049.

KELLER, T. et al. Analysis of soil compression curves from uniaxial confined compression tests. Geoderma, v.163, n1-2, p.1323, 2011. Available from: <http://www.sciencedirect.com/science/ article/pii/S0016706111000425>. Accessed: Jan. 08, 2013. doi: 10.1016/j.geoderma.2011.02.006.

KLUTE, A. Water retention: laboratory methods. In: BLACK, C.A. (Ed.). Methods of soil analysis. I. Physical and mineralogical methods. Madison: American Society of Agronomy, Soil Science Society of America, 1986. p.635-662.

MOSADDEGHI, M.R. et al. Pre-compression stress and its relation with the physical and mechanical properties of a structurally unstable soil in central Iran. Soil and Tillage Research, v.70, n.1, p.53-64, 2003. Available from: <http://www.sciencedirect.com/ science/article/pii/S0167198702001204>. Accessed: 08 Jan. 2013. doi: 10.1016/S0167-1987(02)00120-4.

REINERT, D.J.; REICHERT, J.M. Coluna de areia para medir a retenção de água no solo - protótipos e teste. Ciência Rural, Santa Maria, v.36, n.6, p.1931-1935, 2006. Available from: <http://www.scielo.br/scielo.php?pid=S010006832011000500010\&script $=$ sci_arttext $>$. Acesso em: Jan. 09, 2013. doi: 10.1590/S0103-84782006000600044. 
ROSA, D.P. et al. Métodos de obtenção da capacidade de suporte de carga de um argissolo cultivado. Revista Brasileira de Ciência do Solo, v.35, n.5, p.1561-1568, 2011. Available from: <http://www.scielo.br/scielo.php?pid=S010006832011000500010\&script $=$ sci_arttext $>$. Accessed: Jan. 08, 2013. doi: 10.1590/S0100-068320110005000bbbb10.

RÜCKNAGEL, J. et al. Variance of mechanical precompression stress in graphic estimations using the Casagrande method and derived mathematical models. Soil \& Tillage Research, v.106, n.2, p.165-170, 2010. Available from: <http://www.sciencedirect. com/science/article/pii/S0167198709002013>. Accessed: Jan. 08, 2013. doi: 10.1016/j.still.2009.11.001

SILVA, V.R. et al. Susceptibilidade à compactação de um Latossolo Vermelho-Escuro e de um Podzólico Vermelho-Amarelo. Revista Brasileira de Ciência do Solo, v.4, p.239-249, 2000.

SOIL SURVEY STAFF. Keys to soil taxonomy. 11.ed. Washington DC: USDA-Natural Resources Conservation Service, 2010. 372p. 